\title{
Transfer Pricing Dispute Analysis of PT ABX Fiscal Year 2016
}

\author{
Aristian Yudhistira*, Danny Septriadi \\ Universitas Indonesia \\ Depok, Indonesia \\ *aristianyudhistira@gmail.com
}

\begin{abstract}
This study focuses on the transfer pricing disputes analysis of PT ABX in Fiscal Year 2016. The transfer pricing dispute of PT ABX is a dispute on adjustments made by PT ABX that is not recognized by the Tax Examiner (DGT) in terms of increasing the level of comparability with the Comparable Company in the transfer pricing analysis. This is commonly referred as Comparability Adjustments. Therefore, the purpose of this study is to find out how the analysis of comparability adjustments conducted by PT ABX, DGT's interpretation of adjustments for comparable condition differences carried out by PT ABX and the proof of PT ABX's Comparability Adjustments analysis and DGT interpretation. This study shows that there are 3 relevant comparability adjustments made by PT ABX which are (a) product introduction cost adjustment that proved the product life cycle theory, (b) idle capacity adjustment that proved the theories. where idle capacity will cause fixed costs per unit to rise, and (c) supplier compensation adjustment which is a onetime expense. However, there are 3 irrelevant comparability adjustments made by PT ABX because of the reliability of the adjustments and not in accordance to OECD TP Guidelines and UNTPM which are (a) inventory write-off, (b) increase of labour cost, and (c) forex impact. Also, this study proved that the TNMM's shortcomings are there are possibility of several factors in the financial statements of the companies being tested as well as the comparable companies that affect their financial performance.
\end{abstract}

Keywords-transfer pricing, tax dispute, comparability adjustments

\section{INTRODUCTION}

$\mathrm{PT} \mathrm{ABX}$ is one of the companies engaged in the automotive business in Indonesia. In 2018, PT ABX faced tax audit for the 2016 Fiscal Year. According to PT ABX's tax examiner, there are transfer pricing problems in manufacturing activities transaction in the form of comparability adjustments made to determine the amount of Return on Total Cost (ROTOC) and Operating Margin (OM) PT ABX. This adjustment, according to the examiner, should not be done in calculating profit level indicators (PLI). According to the examiner, adjustments should not only be made to calculate PT ABX profit level indicators, adjustments should be made to the comparable companies PLI as well.
This research is a single case on a single unit analysis which means this study took 1 (one) case, namely the transfer pricing dispute at PT ABX. This research is only limited to the transfer pricing dispute in the 2016 Fiscal Year in accordance with the dispute in the 2016 PT ABX tax audit.

In conducting this research, the author would like to examine the material differences between PT ABX and comparable companies, therefore comparability adjustments are made and know how DGT's perspective in making corrections to these adjustments and also analyze the evidence provided by $\mathrm{PT} \mathrm{ABX}$ in making adjustments and DGT in making corrections.

\section{LITERATURE REVIEW}

TNMM uses net income margins realized by a company in an affiliated transaction then compared to the level of margins obtained by the comparable company to the tested party or the margin set in comparable transactions between independent parties [1]

Arm's length principle is generally based on the comparison of transaction conditions that made with affiliated company with independent transactions, in terms of the economic characteristics of the situation being compared should be quite comparable. This comparison is achieved when there is no difference (if any) between the situations being compared that could materially affect the condition being evaluated (for example price or margin), or reasonably accurate adjustments can be made to eliminate the effects of any of these differences [2].

Important factors include the characteristics of the goods or services delivered, the functions performed between the parties (taking into account also the assets used and the risks), contractual conditions, economic conditions and business strategies taken by the parties [1].

Furthermore, according to Wittendorff [3], the availability of data is often an obstacle in achieving comparability. Generally, the availability of data in the form of empirical data sometimes not available when conducting transfer pricing analysis. This can prevent companies from being able to conduct transfer pricing analysis reliably. The availability of 
empirical data also effecting the governments of the United States and Germany to change their arm's length principle norms that were originally adhering to price-based norms to profit-based norms [3]. In the end, transfer pricing is not an exact science, there will be many conditions where the application of the most appropriate method produces several results which all are relatively reliable [4].

To meet arm's length, adjustments to material differences between the parties being tested and the comparable companies must be made to achieve comparability. In accordance with the 2013 UN Transfer Pricing Manual for Developing Countries $[4,5]$, there are a number of important things that must be considered before adjustments can be made: Data quality; The purpose of the adjustment made; Not every tested transaction can be adjusted; Reliability and accuracy of adjustments; Documentation.

Divides comparability adjustments into 3 categories [6], which is accounting adjustments, working capital adjustments, and other adjustments. Comparability adjustments in other countries are also conducted by referring to the arm's length principle and comparability.

For example, comparability adjustments in the United States are based on one of the three requirements in the Internal Revenue Service Code Section 482 (IRC 482), which is the Internal Revenue Service (IRS)/ United States tax authority must ensure that whether allocation of costs is needed in order prevent tax avoidance or to be able to reliably reflect the income of one of the parties tested. This requirement is needed if an affiliate transaction does not meet the arm's length, therefore the IRS can make adjustments to the transaction so that the transaction can meet the arm's length. However, there is an explanation in the regulation if the company knows, based on facts and circumstances, affiliated transactions do not meet the arm's length, the company can submit a comparability adjustment proposal called a Notice of Proposed Adjustment (NOPA). Facts and circumstances that require companies in the United States to do comparability adjustments must look at 2 points in accordance with IRC 482, which is (i) whether income or income deduction is in accordance with the functions performed between the tested party and comparable companies; and (ii) whether the party tested or comparable company has a unique function that does not function between the two so as to generate greater income from one of the parties.

Comparability adjustments in the transfer pricing analysis are also permitted by the Government of India in accordance with Rule 10B (3) Indian Income-tax Rules which states that for the sake of comparability between the tested companies and the comparison companies, adjustments can be made in terms of eliminating material differences between companies that tested and comparison companies. The Indian government also mentioned that there are factors that must be considered in comparability adjustments, which is the quality of adjustments made, the purpose of the adjustments made, and the reliability of the adjustments made [7].
The burden of proof should be based on facts and circumstances. In a tax dispute, especially on comparability adjustments, burden of proof should be divided proportionally according to the arguments obtained from the company or the tax authority. This is to eliminate subjectivity in carrying out comparability adjustments in transfer pricing analysis [8].

New product introductions (introduction cycle) is a period where products developed in the previous cycle begin to be marketed and introduced to potential customers. At this stage the company usually does not make a profit because in this cycle the costs incurred by the company are huge while the sales achieved tend to be low [9].

One-time expense is a cost that only occurs once and will not recur in the next period [10]. These costs will be sunk costs in the next period, where, for the purposes of analysis these costs are less considered or cannot be considered at all [10].

Adjustment of production capacity that caused by idle capacity can be caused by several factors including: Labour unrest; Low demand; Reduction in turnover [11].

Based on his research on automotive manufacturers in the United States and Germany in 2003 to 2013, automotive manufacturers can achieve a break-even point if their production capacity runs in the range of $75 \%-80 \%$ of full production capacity [12].

The fixed costs of using production capacity are not directly connected to the decrease in production capacity due to idle capacity. Overall fixed costs will remain stagnant in terms of idle capacity or if production capacity is utilized in full capacity. But in terms of idle capacity or under-utilization, the fixed costs per unit will experience a significant increase $[6,11]$. Therefore, this certainly affects the level of companies' net income. There are 3 exposures caused by forex impact, namely transaction exposure, economic exposure and translation exposure [13].

The effect of forex impact can also occur due to government policies related to the foreign exchange rate system. There are 2 basic systems in foreign exchange policy that can be taken by the government, which is fixed exchange rate and floating exchange rate [14]. Fixed exchange rate means that the government controls and determines the exchange rate of foreign currencies independently by not seeing the demand and supply available in the foreign currency market. Conversely, a floating exchange rate is a foreign exchange rate that follows the demand and supply in the foreign exchange market, which means that this exchange rate system will cause a fluctuation in the domestic currency.

\section{METHODS}

This case study research uses a qualitative research approach where the authors aim to obtain descriptive analysis (how and why) related to the transfer pricing dispute at PT ABX. This research is a case study with single case on single unit analysis where this research takes 1 (one) case, namely the 
transfer pricing dispute at PT ABX which is the only object of research.

This study collected data through analysis of documentation and archive records owned by PT ABX. In addition, the authors also conducted a literature study in accordance with the data collected through the analysis of documentation and archival records. The data collected consists of primary data and secondary data.

\section{RESULTS AND DISCUSSION}

\section{A. Results}

$\mathrm{PT} \mathrm{ABX}$ recorded a loss for 4 consecutive years which is different from comparable companies that have good financial performance, so that comparable adjustments are needed in the analysis of transfer pricing. This loss is caused by several factors including:

Product introduction cost caused a loss of around 34\% of the overall operating loss of PT ABX in the Fiscal Year 2016. The cost of inventory elimination has a percentage of around $4 \%$ of all operational losses suffered by PT ABX in the Fiscal Year 2016

In the 2016 Fiscal Year, PT ABX only used $21 \%$ of its maximum production capacity. The decrease in production capacity causes an increase in fixed costs of around $632 \%$ in plant 1 and $185 \%$ in plant 2 of normal fixed costs. While the effect of under-utilization for PT ABX's operational loss is around 30\% in Fiscal Year 2016.

The low production capacity causes the failure to fulfill the minimum purchase of raw materials from suppliers agreed by both parties between PT ABX and suppliers so that PT ABX in the Fiscal Year 2016 must pay compensation to suppliers. The increase of labour cost that around $12 \%$ is something that cannot be avoided by PT ABX because it has been regulated in a Regional Government Regulation. PT ABX assumes that the increase in labour costs usually near the inflation rate where for 2016, while the Indonesian inflation rate of 2016 is only $3.02 \%$

All of PT ABX comparable companies are located in China, where the Chinese currency does not fluctuate significantly against the USD. So, PT ABX made adjustments to the effect of foreign exchange rates by looking in the discrepancy between Export Sales and Import Purchases for the Fiscal Year 2016 using the BI exchange rate of the Fiscal Year 2016 and using the BI exchange rate in the Fiscal Year 2015. Adjustments were made on that discrepancy.

- In making comparability adjustments, PT ABX should treat the similar thing for the comparable company's Operating Margin;

- TNMM is using level of the net profit indicator that means the differences in capacity, marketing functions and others have indirectly been reduced in the calculation;

- Adjustments made by PT ABX, especially for capacity adjustments and product adjustments that do not sell in the market are adjustments that should have been anticipated by the company. So, adjustments should not be made.

Table 1 below is the evidence submitted by PT ABX for the comparability adjustments made:

TABLE I. PROOF SUBMITTED BY PT ABX

\begin{tabular}{|c|c|c|c|c|c|c|}
\hline No & $\begin{array}{c}\text { Product } \\
\text { Introduction Cost } \\
\text { (PIC) }\end{array}$ & Inventory write-off & $\begin{array}{c}\text { Production } \\
\text { Capacity Under } \\
\text { Utilization }\end{array}$ & $\begin{array}{c}\text { Supplier } \\
\text { Compesation }\end{array}$ & $\begin{array}{c}\text { Increase of Labour } \\
\text { Cost }\end{array}$ & Forex Impact \\
\hline 1 & $\begin{array}{l}\text { PIC press } \\
\text { conference } \\
\text { documentation }\end{array}$ & $\begin{array}{l}\text { Inventory write off } \\
\text { minutes of meeting }\end{array}$ & Production report & $\begin{array}{l}\text { Purchasing } \\
\text { agreement }\end{array}$ & $\begin{array}{l}\text { West Java Governor } \\
\text { Decree } \\
\text { No.561.Kep.1322- } \\
\text { Bangsos/2015 }\end{array}$ & $\begin{array}{l}\text { Forex fluctutation of } \\
\text { IDR against USD } \\
\text { and CNY against } \\
\text { USD }\end{array}$ \\
\hline 2 & $\begin{array}{l}\text { Minutes of Meeting } \\
\text { product introduction } \\
\text { and marketing date. }\end{array}$ & $\begin{array}{l}\text { Inventory report and } \\
\text { audit report } \\
\text { inregards of } \\
\text { inventory write off }\end{array}$ & $\begin{array}{l}\text { Production capacity } \\
\text { blueprint of PT ABX }\end{array}$ & & & $\begin{array}{ll}\text { Forex } & \text { Impact } \\
\text { adjustment } & \\
\text { calculation } & \end{array}$ \\
\hline
\end{tabular}

However, the DGT did not submit any evidence in its interpretation.

\section{B. Discussion}

The product introduction costs experienced by PT ABX has proved the product life cycle theory, in the product introduction cycle company will suffer losses because the company must bear high introductory costs, but sales achieved tend to be low [9]. The percentage of losses experienced due to the cost of introducing new products also tends to be high, this proves that these factors are material.

Adjustment to the cost of introducing new products is precisely done by $\mathrm{PT} \mathrm{ABX}$ in the analysis of transfer pricing. This is because PT ABX's financial performance shows that PT $\mathrm{ABX}$ is experiencing a business decline where the Comparable Company (with the criteria for searching for a comparable company that has been carried out by PT ABX) is believed to have a normal operation. This is also in line with Wittendorff 
[3] theory, and the comparable theory that exists in OECD [4], United Nations [5].

Although the inventory write-off is a one-time expense, authors found that in the 2016 PT ABX audited financial statements, PT ABX's inventories have been insured and PT $\mathrm{ABX}$ has also recorded reserves for inventory losses. Which means that for the inventory write-off, PT ABX has taken preventative measures against the possibility of inventory losses. This causes the reliability of comparability adjustments made by PT ABX not in accordance with those in OECD [4], United Nations [5].

The condition experienced by $\mathrm{PT}$ ABX is in accordance with theory which states that under-utilization of production capacity can be caused by falling demand for products at the company or can be called a company experiencing a business decline $[6,11]$. The decline in production capacity also resulted in materially raised fixed costs per unit.

In the fiscal year 2016, PT ABX experienced underutilization of production capacity so that fixed costs per unit rose significantly. This proves the theories of Jindal [6] and Roedl [11], where idle capacity will cause fixed costs per unit to rise. The greater idle capacity experienced by PT ABX, the impact of fixed costs will be more significant.

PT ABX has made an appropriate adjustment to underutilization of production capacity in the transfer pricing analysis. This is because PT ABX's financial performance shows that PT ABX is experiencing a business decline where the Comparable Company (with the criteria for searching for a comparable company that has been carried out by PT ABX) is believed to have a normal operation.

Adjustment of supplier compensation is appropriate because it is a one-time expense and the evidence is reliable. This is because PT ABX's financial performance shows that PT $\mathrm{ABX}$ is experiencing a business decline where the Comparable Company (with the criteria for searching for a comparable company that has been carried out by $\mathrm{PT} \mathrm{ABX}$ ) is believed to have a normal operation.

According to the author's analysis, the comparable company of PT ABX experienced the same thing. All comparison companies in China experienced a significant percentage increase in labour costs to around 17\% [15], and China's inflation rate in 2016 was only 2\% [16]. Therefore, comparability adjustments related to increase of labour costs are irrelevant because the conditions of PT $\mathrm{ABX}$ and the comparable companies are same.

Forex impact in PT ABX will cause exposure including transaction exposure and translation exposure. This is consistent with what was expressed by Faisal [13]. In its calculations, PT ABX only adjusted the effect of foreign exchange rates only on PT ABX's financial performance, but it was not carried out to the Comparable Companies. Even though the Comparable Company fluctuates insignificantly, if PT ABX makes adjustments using the comparison of the mean value of the previous Fiscal Year exchange rate, PT ABX should also do the same for the comparable company. So as to achieve comparability.

As stated in the analysis, the comparable company's financial performance shows that the comparable company is not experiencing a business downturn, this is reflected in the financial performance of the comparable company that has not experienced loss for more than 2 years. So that the economic conditions experienced by the comparable company and PT $\mathrm{ABX}$ are different and a reliable adjustment must be made and in accordance with the available data; The DGT interpretation of TNMM is just an assumption. In accordance with the literature review, TNMM's shortcomings are the possibility of several factors in the financial statements of the companies being tested as well as the comparable companies that affect their financial performance [17]. Thus, comparability adjustments are still needed in order to produce a more reliable net margin [1], DGT said that the adjustment due to underutilization of production capacity should have been anticipated by PT ABX so that the adjustment was not allowed. In this case, DGT did not analyze in detail the effect of underutilization of production capacity on PT ABX. Like how much material differences on the under-utilization of production capacity at PT ABX.

\section{CONCLUSION}

This study is limited only to transfer pricing disputes in the 2016 Fiscal Year in accordance to PT ABX tax audit. According to the author's analysis, comparability adjustments have been appropriately carried out by PT ABX on product introduction costs, production capacity under-utilization and supplier compensation. However, there are 3 improper comparability adjustments, namely adjustments in inventory write-off, increase of labor cost, and forex impact.

Whereas in the DGT's interpretation in making corrections, DGT should specify all the comparability adjustment factors made by PT ABX. So that DGT's interpretation of comparability adjustments made by $\mathrm{PT}$ ABX can be more relied.

Also, in its interpretation, DGT should support the interpretation on the basis of relevant laws, evidence and references. And if indeed in the analysis of the transfer pricing of taxpayers (PT ABX) proven by evidence, the legal basis and relevant references have different conditions that are not comparable with the comparable company, the DGT should be able to accept the adjustments made by taxpayers in order to increase comparability between the parties. This is to provide legal certainty for companies that are examined specifically in the analysis of transfer pricing.

\section{REFERENCES}

[1] R. Feinschreiber, Transfer pricing methods: an applications guide. John Wiley \& Sons, 2004.

[2] J.J. Loots, A comparability adjustment transfer pricing model. NorthWest University, 2006. 
[3] J. Wittendorff, Transfer pricing and the arm's length principle in international tax law. Kluwer Law International BV, 2010.

[4] OECD, OECD Transfer Pricing Guidelines for Multinational Enterprises and Tax Administrations 2017. Paris: OECD Publishing.

[5] United Nations, UN Practical Manual on Transfer Pricing for Developing Countries. New York: United Nations, 2013.

[6] H.O. Jindal, Transfer Pricing in Relation to International Transactions. Delhi: Young Global Publications, 2015.

[7] A.K. Jain and R. Thakkar, "Capacity utilization adjustments during startup phase," 2015.

[8] A. Navarro, Transactional Adjustments in Transfer Pricing. IBFD, 2017.

[9] G. Armstrong, S. Adam, S. Denize and P. Kotler, "Principles of marketing," Pearson Australia, 2014

[10] P. Atrill, E. McLaney and D. Harvey, "Accounting: An Introduction, 6/E," Pearson Higher Education AU, 2014.

[11] R. Roedl, India: Capacity Utilization Adjustment. 2015.
[12] H. Kallstrom, "High operating leverage impacts the auto industry," 2015.

[13] M. Faisal, Manajemen Keuangan Internasional. Jakarta: Salemba Empat, 2001.

[14] E.F. Brigham and J.F. Houston, "Fundamentals of financial management," Cengage Learning, 2012.

[15] A. Shu, China Minimum Wage Updates 2016, SGS Group Management SA, $2016 \quad$ [Online]. Retrieved from:https://www.sgs.com/en/news/2016/11/safeguards-17416-chinaminimum-wage-updates-2016.

[16] Macrotrends, China Inflation Rate 1987-2019: Macrotrends LLC, 2019 [Online]. Retrieved from: https://www.macrotrends.net/countries/CHN/china/inflation-rate-cpi.

[17] N. Boquist, The Transactional Net Margin Method: A transfer pricing method in theory and practice, 2009. 